THE FOUR AGES OF TSURAI 


\section{THE FOUR}

A DOCUMENTARY HISTORY OF THE

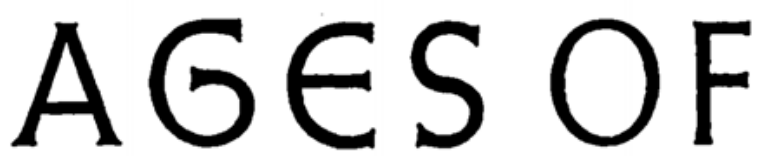

INDIAN VILLAGE ON TRINIDAD BAY

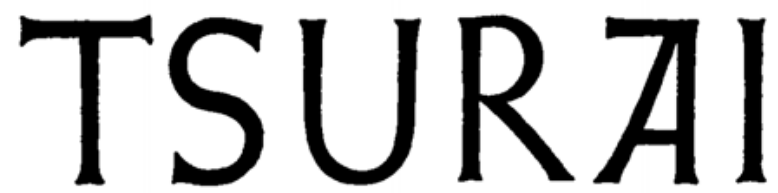

\section{Robert F. Heizer and John E. Mills}

Translations of Spanish Documents by Donald C. Cutter

UNIVERSITY OF CALIFORNIA PRESS

BERKELEY AND LOS ANGELES》 1952 
UNIVERSITY OF CALIFORNIA PRESS Berkeley and Los Angeles

California

CAMBRIDGE UNIVERSITY PRESS

London, England

Copyright, 1952, by

THE REGENTS OF THE UNIVERSITY OF CALIFORNIA

Printed in the United States of America

by the University of California Press

Designed by Adrian Wilson 